Article

\title{
Enhancing the Leaching of Chalcopyrite Using Acidithiobacillus ferrooxidans under the Induction of Surfactant Triton X-100
}

\author{
Ruiyang Zhang ${ }^{1}{ }^{\mathbb{D}}$, Chunbao Sun ${ }^{1}$, Jue Kou ${ }^{1}$, Hongyu Zhao ${ }^{1}$, Dezhou Wei ${ }^{2}$ and Yi Xing ${ }^{3, *}$ \\ 1 School of Civil and Resource Engineering, University of Science and Technology Beijing, Beijing 100083, \\ China; zhangruiyang@ustb.edu.cn (R.Z.); suncb@ustb.edu.cn (C.S.); koujue@ustb.edu.cn (J.K.); \\ yuyu_3003@126.com (H.Z.) \\ 2 School of Resources and Civil Engineering, Northeastern University, Shenyang 110819, China; \\ dzwei@mail.neu.edu.cn \\ 3 School of Energy and Environmental Engineering, University of Science and Technology Beijing, \\ Beijing 100083, China \\ * Correspondence: xingyi_team@126.com
}

Received: 27 October 2018; Accepted: 20 December 2018; Published: 25 December 2018

\begin{abstract}
Chalcopyrite is the richest copper sulfide mineral in the world, but it is also the most resistant to biohydrometallurgical processing. To promote the bioleaching of chalcopyrite, a nonionic surfactant, t-octyl phenoxy polyethoxy ethanol (Triton X-100), was employed in this paper. Action of Triton X-100 in chalcopyrite leaching using Acidithiobacillus ferrooxidans was explored in shake flasks. Results showed that $30 \mathrm{mg} \cdot \mathrm{L}^{-1}$ of Triton X-100 increased the bioleaching yield of copper by $42.21 \%$ compared to the process without additive after 24 days. Under the stress of Triton X-100, the bioleaching efficiency of chalcopyrite slightly dropped at an early stage, but remarkably increased afterwards. XRD and XPS analysis of the leach residues demonstrated that potassium jarosite and elemental sulfur resulted in surface leaching passivation. Surfactant Triton X-100 appeared to induce the oxidation of elemental sulfur by bacteria owing to the increase in the sulfur surface hydrophobicity. These results suggest that Triton X-100 itself has no ability to leach chalcopyrite, but under its induction, the bioleaching of chalcopyrite can be enhanced due to the removal of the passivation layer.
\end{abstract}

Keywords: chalcopyrite; surfactant; bioleaching; surface passivation; induction

\section{Introduction}

Chalcopyrite $\left(\mathrm{CuFeS}_{2}\right)$ is the richest copper-bearing mineral, accounting for nearly two-third of the world's copper reserves [1], while it is also extremely recalcitrant to (bio)hydrometallurgical processing [2] In practice, industrial-scale bioleaching is generally carried out by the use of mesophilic microorganisms like Acidithiobacillus ferrooxidans, Acidithiobacillus thiooxidans, and Leptospirillum ferrooxidans because they are dominant species at normal atmospheric temperatures [3]. Slow oxidation kinetics and low copper recovery are the bottlenecks of chalcopyrite's commercial application in meso-acidophilic bioleaching [4]. These can be mainly attributed to two factors: (i) the high lattice energy of chalcopyrite, making it difficult to decompose; and (ii) the formation of a surface passivation film during chalcopyrite bioleaching, which is made up of sulfur-containing intermediates such as elemental sulfur, jarosite, polysulphides, and metal-deficient sulphides $[5,6]$. To prevent such passivation, many approaches have been proposed, for example, use of thermophilic microorganisms [7], lowering $\mathrm{pH}$ conditions [8], controlling the redox potential [9], and the addition of catalysts like silver and activated carbon [10,11]. Although each method possesses its own advantages of high activity of bacteria, high reaction efficiency, 
complete dissolution, or simple technique, it should be noted that they do have specific drawbacks such as a low metal tolerance capability, high acid consumption, complicated process, or high operation cost, which limit their application in industry.

Additionally, adding an appropriate amount of surfactant featuring specific structure has been found to be a potential way to promote the leaching [12]. Previous studies showed that the addition of surfactants such as polysorbate (Tween), p-octyl polyethylene glycol phenyl ether (emulsifier $\mathrm{OP})$, o-phenylenediamine (OPD), or potassiumamyl xanthate (KAX), could result in the enhanced bioleaching of cobalt ore [13], arsenopyrite [14], marmatite [15], or zinc sulphide, respectively [16]. Most researchers have simply attributed this positive impact to the fact that surfactants can change surface properties of minerals and the interfacial tension of the leaching solution [13], but so far, no direct evidence can verify the cause-and-effect relationship between these changes and the leaching rate.

In the case of chalcopyrite, only the nonionic surfactants Tweens have been investigated. Hiroyoshi et al. reported that adding $20 \mathrm{mg} \cdot \mathrm{L}^{-1}$ of Tween 20 was favorable for the copper extraction from chalcopyrite [17]. The author believed that indirect leaching played the main role in the bioleaching, and the catalytic effect was attributed to the decrease in the bacterial adhesion to the chalcopyrite surface. Peng et al. also reported that $10 \mathrm{mg} \cdot \mathrm{L}^{-1}$ of Tween 80 increased the copper leaching efficiency by $16 \%$, possibly due to the shortening of the lag stage of bacteria growth [18]. However, the catalytic capability of Tweens is rather limited, mainly due to its toxicity for bioleaching microorganisms [19]. Hence, there is a need to develop more effective but less toxic surfactants for catalyzing the bioleaching of chalcopyrite.

Triton X-100, formally named as t-octyl phenoxy polyethoxy ethanol, is a water-soluble nonionic surfactant with an aromatic hydrocarbon and branched alkyl substituent as a hydrophobic group and a polyethylene oxide chain as a hydrophilic group. Chemical structure of Triton X-100 is shown in Figure 1. It is widely used as a solubilizer, detergent, or dispersing or wetting agent due to its chemical stability, good wettability, and low toxicity [20,21]. Interestingly, our previous research showed that Triton X-100 could accelerate the bioleaching rate of chalcopyrite, though it has a detrimental impact on ferrous-oxidizing activity of bioleaching microorganisms [22]. However, little information has been done on its effect on the oxidation process, and on the formation of surface passivation films. It is clear that understanding its mechanism could offer a new alternative for the enhancement of copper recovery via bacterial leaching.<smiles>CC(C)(C)CC(C)(C)c1ccc(OCCCCCO)cc1</smiles>

Figure 1. Chemical structure of surfactant Triton X-100.

In this study, the influences of Triton $\mathrm{X}-100$ on the chalcopyrite leaching via Acidithiobacillus ferrooxidans were investigated in shake flasks. Moreover, further analysis of the chalcopyrite surface after leaching were characterized using X-ray diffractometer (XRD), scanning electron microscope (SEM), X-ray photoelectron spectroscopy (XPS). Finally, a model for the catalytic action of Triton X-100 was proposed. This work would provide a deeper insight into the catalytic mechanism of surfactant (i.e., Triton X-100) in chalcopyrite bioleaching.

\section{Materials and Methods}

\subsection{Bacteria and Minerals}

The meso-acidophilic strain Acidithiobacillus ferrooxidans XZ11, GenBank accession number KJ573102, used in this paper was isolated from the acid mine water of a Jiama copper mine in Tibet, China. The $0 \mathrm{~K}$ medium was composed of $3.0 \mathrm{~g} \cdot \mathrm{L}^{-1}\left(\mathrm{NH}_{4}\right)_{2} \mathrm{SO}_{4}, 0.1 \mathrm{~g} \cdot \mathrm{L}^{-1} \mathrm{KCl}, 0.5 \mathrm{~g} \cdot \mathrm{L}^{-1} \mathrm{~K}_{2} \mathrm{HPO}_{4}$, $0.5 \mathrm{~g} \cdot \mathrm{L}^{-1} \mathrm{MgSO}_{4} \cdot 7 \mathrm{H}_{2} \mathrm{O}$, and $0.01 \mathrm{~g} \cdot \mathrm{L}^{-1} \mathrm{Ca}\left(\mathrm{NO}_{3}\right)_{2}$. The $9 \mathrm{~K}$ medium was composed of the $0 \mathrm{~K}$ medium with $\mathrm{FeSO}_{4} \cdot 7 \mathrm{H}_{2} \mathrm{O}\left(44.2 \mathrm{~g} \cdot \mathrm{L}^{-1}\right)$ added as the sole energy resource for bacteria. Also, the sulfur medium 
consisted of the $0 \mathrm{~K}$ medium and $1 \%(w / v)$ of sulfur powder. The initial $\mathrm{pH}$ of these three media was adjusted to 2.0 with sulphuric acid. All of the reagents were of analytical grade, which were purchased from Sinopharm Chemical Reagent Co., Ltd., Shanghai, China.

To obtain metabolite-free cells, bacteria inoculated in a bacterial adhesion $\left(5 \times 10^{7}\right.$ cells $\left.\cdot \mathrm{mL}^{-1}\right)$ and leaching experiments $\left(2 \times 10^{7}\right.$ cells $\left.\cdot \mathrm{mL}^{-1}\right)$ were cleaned as follows. First, bacteria cultured in $9 \mathrm{~K}$ medium were collected in the stationary phase. Then, the culture was filtered through Whatman filter paper No. 42 to remove precipitates and centrifuged at 10,000 rpm for $15 \mathrm{~min}$. Finally, the cells were washed and resuspended in the $0 \mathrm{~K}$ medium.

The highly pure chalcopyrite used in this paper was collected from Yunnan province in China. The sample was crushed, hand selected, and further purified using a shaking table. Then, the obtained high-purity chalcopyrite was ground until all particles passed through $74 \mu \mathrm{m}$ before being used for leaching experiment. Powder X-ray diffraction data confirmed chalcopyrite to be the only detectable mineral phase. Chemical analysis showed that the chalcopyrite contained: $\mathrm{Cu} 32.84 \%$; Fe 29.62\%; S $33.10 \%$.

\subsection{Surface Tension and Contact Angle Measurements}

The surface tension of Triton X-100 (chemically pure) solutions was measured in 0K medium at 30 $\pm 1{ }^{\circ} \mathrm{C}$ using the Wilhelmy plate technique with a tensiometer (JF99C, Zhongchen Digital Technology and Equipment Co., Ltd., Shanghai, China). The contact angles of elemental sulfur surface were measured by a contact angle analyzer (XG-CAMB, Xuanyi Digital Technology and Equipment Co., Ltd., Shanghai, China). Sulfur powders were pressed into pellets (5 $\mathrm{mm}$ thick and $10 \mathrm{~mm}$ in diameter), and successively polished with 400-, 800-, and 1000-grit silicon carbide papers, to ensure uniform smoothness. The deionized water and the aqueous solution containing Triton X-100 at various concentrations were dropped onto the pellets surface using a special syringe, and then the static contact angle was measured at room temperature $\left(25 \pm 2{ }^{\circ} \mathrm{C}\right)$. For each group, five measurements were carried out, and the average value was calculated.

\subsection{Bacterial Adhesion Experiments}

Bacterial adhesion to elemental sulfur was studied as described previously [23]. The experiments were carried out in 250-mL flasks containing $100 \mathrm{~mL}$ of $0 \mathrm{~K}$ medium, $1 \%(w / v)$ of sulfur powder, $5 \times$ $10^{7}$ cells $\cdot \mathrm{mL}^{-1}$ of $A$ t. ferrooxidans, and a predetermined amount of Triton $\mathrm{X}-100$. Each flask was shaken at $160 \mathrm{rpm}$ and $30{ }^{\circ} \mathrm{C}$ for $30 \mathrm{~min}$. Then, the mixture was filtered through a filter paper (Whatman No. 1) to remove cells-bearing sulfur powder. Finally, cell numbers in the filtrate was determined using a Neubauer-improved counting chamber (Cell depth: $0.1 \mathrm{~mm}$; Ruling pattern 1/400 $\mathrm{mm}^{2}$; XB-K-25, Shanghai, China) under a microscope (Motic BA210, Xiamen, China). The bacterial adhesion percentage $(\eta)$ was calculated using the equation $\eta=\left(c_{0}-c\right) / c_{0} \times 100 \%$, where $c_{0}$ and $c$ represent the initial number and the cell number in the filtrate, respectively. Each group was carried out in triplicate, and the average value was reported.

\subsection{Ferrous Iron and Sulfur Oxidation Measurements}

Ferrous iron or sulfur oxidation by At. ferrooxidans were determined in $250 \mathrm{~mL}$ Erlenmeyer flasks, in a shaking incubator with $160 \mathrm{rpm}$ at $30^{\circ} \mathrm{C}$. Each flask contained $90 \mathrm{~mL}$ of $9 \mathrm{~K}$ media or sulfur media, $10 \mathrm{~mL}$ of bacteria that was harvested during the stationary phase of growth, and a predetermined amount of Triton X-100. The ferrous iron concentration was measured by titration with a standard solution of potassium dichromate, and sodium diphenylamine sulphonate was employed as an indicator. The rate of sulfur oxidation was estimated by the decrease of $\mathrm{pH}$ value of the medium. Then, the $\mathrm{pH}$ value of each group was determined periodically using a digital $\mathrm{pH}$ meter (Sartorius PB-10, Goettingen, Germany). Each group was carried out in triplicate. 


\subsection{Leaching Experiments}

Leaching experiments were carried out in $250 \mathrm{~mL}$ Erlenmeyer flasks, in a shaking incubator with $160 \mathrm{rpm}$ at $30{ }^{\circ} \mathrm{C}$. Each flask contained $100 \mathrm{~mL}$ of the $0 \mathrm{~K}$ medium, $1 \%(w / v)$ of chalcopyrite and a predetermined amount of Triton X-100. The initial number of bacteria was adjusted to $2 \times$ $10^{7}$ cells $\cdot \mathrm{mL}^{-1}$ in the bioleaching systems, while $0.1 \mathrm{~g} \cdot \mathrm{L}^{-1}$ of NaF serving as a bacteriostat was added in abiotic leaching systems in the absence of cells. Each group was carried out in triplicate.

Samples were taken periodically to determine the concentrations of bacteria and metal ions. The concentrations of soluble copper and total iron were determined using inductively coupled plasma optical emission spectroscopy (Perkin Elmer, Waltham, MA, USA). $\mathrm{Fe}^{3+}$ concentration was calculated using the difference between total $\mathrm{Fe}$ and $\mathrm{Fe}^{2+}$ concentration. The water lost due to evaporation and sampling were compensated with deionized water and the $0 \mathrm{~K}$ medium, respectively.

After 24 days of bioleaching, the pulp was filtered, and the residues were collected, washed carefully with deionized water, and then dried in a vacuum at $30{ }^{\circ} \mathrm{C}$. Then, the residues were characterized using an X-ray diffractometer (PAN-alytical X'Pert Pro, Almelo, The Netherlands) and X-ray photoelectron spectroscopy (ESCALAB 250, Waltham, MA, USA), respectively. XRD measurements were tested with $\mathrm{Cu} \mathrm{K} \alpha$ radiation $(\lambda=0.154 \mathrm{~nm}, 40 \mathrm{kV}, 40 \mathrm{~mA})$ and a scanning step of $2^{\circ} / \mathrm{min}$. The results were analyzed using the built-in software $X^{\prime}$ Pert HighScorePlus. XPS measurements were conducted with a monochromatic Al-K $\alpha$ source. All spectra were calibrated with the $\mathrm{C} 1 \mathrm{~s}$ peak at $284.8 \mathrm{eV}$, and the obtained data was processed by fitting a Shirley background. In addition, after 24 days, a small amount of pulp containing minerals was deposited onto metallic substrates $(1 \mathrm{~cm} \times 1 \mathrm{~cm})$ covered with a double-adhesive carbon tape, and then washed carefully with deionized water, and finally dried in a vacuum at $30^{\circ} \mathrm{C}$. Afterward, the dehydrated samples were covered with gold to be visualized using a scanning electron microscope (SEM, ZEISS Ultra Plus, Oberkochen, Germany). Further details can be found in previous works [24-26].

\section{Results and Discussion}

\subsection{The Iron-Oxidizing Activity of At. ferrooxidans}

Once an additive is added into the bacterial leaching system, the priority should be given to its possible toxic/inhibitory effect to the growth of bacteria. Influences of Triton X-100 on the iron-oxidizing activity of At. ferrooxidans are shown in Figure 2A. It was shown that the ferrous iron oxidation rate decreased with increasing Triton X-100 concentrations. Without the surfactant addition, the ferrous iron was completely oxidized in approximately $60 \mathrm{~h}$, and the oxidation rate was up to $0.34 \mathrm{~g} \cdot \mathrm{L}^{-1} \cdot \mathrm{h}^{-1}$. When the concentration fell within the range of 30 to $90 \mathrm{mg} \cdot \mathrm{L}^{-1}$, the oxidation rate was gradually decreased from 0.33 to $0.15 \mathrm{~g} \cdot \mathrm{L}^{-1} \cdot \mathrm{h}^{-1}$. Exposure to $200 \mathrm{mg} \cdot \mathrm{L}^{-1}$ of Triton X-100 made the bacteria nearly lose the iron-oxidizing ability. These data indicated that the Triton X-100 addition was inhibitory for ferrous iron oxidation by At. ferrooxidans, even at low doses. As reported previously, most of organic compounds cannot be metabolized by At. ferrooxidans, as a chemosynthetic autotrophic bacterium, and usually inhibit the growth activity of the bacteria $[27,28]$.

Figure 2B illustrates the change in surface tension of solution with the addition of varying concentrations of Triton X-100. It was shown that the higher the Triton X-100 concentration, the lower the surface tension of solution. In the presence of $200 \mathrm{mg} \cdot \mathrm{L}^{-1}$ of Triton X-100, the surface tension decreased from 67.84 (without additive) to $38.50 \mathrm{mN} \cdot \mathrm{m}^{-1}$. According to the reports by Torma and Liu et al., the bacterial activity of At. ferrooxidans and the surface tension of the medium were inversely proportional to the concentration of surfactants Tween 20,40, 60, and $80[19,29]$. Thus, it was concluded that the decay in the iron-oxidizing ability of At. ferrooxidans in the presence of Triton X-100 is probably the consequence of the decrease in the surface tension of solution. 

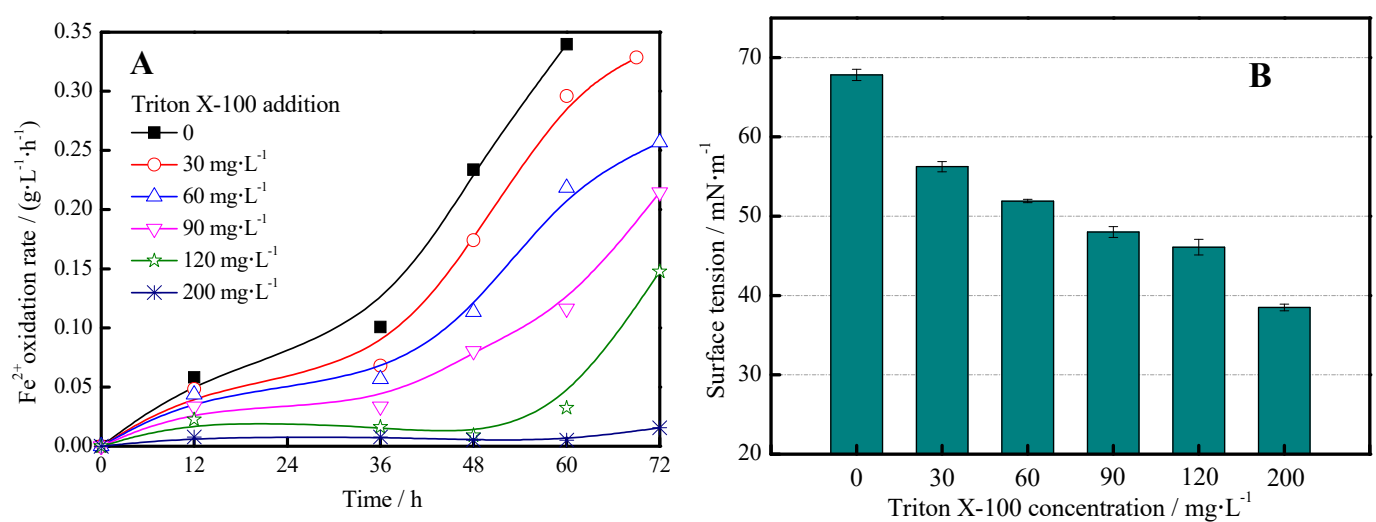

Figure 2. Influences of Triton X-100 on iron-oxidizing activity of At. ferrooxidans and on the surface tension of solution: (A) bacteria inoculation $10 \%(v / v)$, initial $\mathrm{Fe}^{2+} 8.9 \mathrm{~g} \cdot \mathrm{L}^{-1}$, initial $\mathrm{pH} 2.0$, rotational speed $160 \mathrm{rpm}$, and temperature $30{ }^{\circ} \mathrm{C}$; (B) $\mathrm{Fe}^{2+} 0 \mathrm{~g} \cdot \mathrm{L}^{-1}, \mathrm{pH} 2.0$, and temperature $30^{\circ} \mathrm{C}$.

\subsection{The Induction of Sulfur Oxidation by At. ferrooxidans}

Apart from the oxidation of the ferrous iron $\left(\mathrm{Fe}^{2+}\right)$, sulfur oxidation is the other important ability of At. ferrooxidans. It has been demonstrated that the oxidation of elemental sulfur $\left(\mathrm{S}^{0}\right)$ by sulfur-oxidizing bacteria occurs at the cell envelope, thus the adhesion of bacterial cells to sulfur particles is necessary [30]. In such a process, the hydrophobic barrier must be overcome first.

Figure $3 \mathrm{~A}$ illustrates the influences of Triton X-100 on $\mathrm{S}^{0}$ surface hydrophobicity (characterized by contact angle) and on the adhesion of At. ferrooxidans to $\mathrm{S}^{0}$. The results showed that the contact angle of $S^{0}$ declined gradually with increasing Triton X-100 amount. The contact angle between water and $\mathrm{S}^{0}$ surface was $105.4^{\circ}$, suggesting that $\mathrm{S}^{0}$ surface was highly hydrophobic, whereas the contact angle decreased to $60.1^{\circ}$ under the stress of $120 \mathrm{mg} \cdot \mathrm{L}^{-1}$ Triton X-100. Thus, it can be seen, Triton X-100 addition could significantly improve the surface hydrophilicity of $S^{0}$. This might be because the hydrophobic part of Triton X-100, isooctyl phenyl ether, was absorbed on $S^{0}$ surface by van der Waals interactions, and the hydrophilic part (i.e., oligo-ethylene oxide) was oriented toward the aqueous phase, forming a hydrophilic layer on the $\mathrm{S}^{0}$ surface.
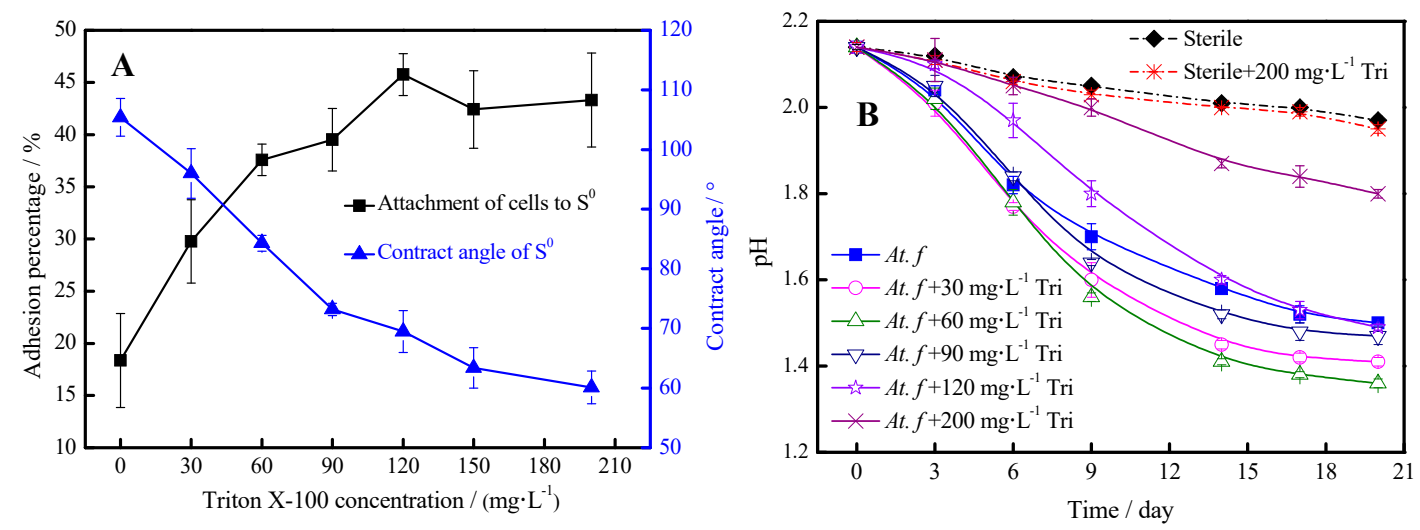

Figure 3. Influences of Triton $X-100$ on contact angle of $S^{0}$ and bacterial attachment to $S^{0}$, as well as on the oxidation of $S^{0}$ : (A) $S^{0} 1 \%(w / v)$, bacteria inoculation $5 \times 10^{7}$ cells $\cdot \mathrm{mL}^{-1}$, temperature $30{ }^{\circ} \mathrm{C}$, and adsorption time $30 \mathrm{~min}$; (B) $\mathrm{S}^{0} 1 \%(w / v)$, bacteria inoculation $10 \%(v / v)$, initial pH 2.1, and temperature $30^{\circ} \mathrm{C}$.

Figure 3A also showed that Triton X-100 addition observably enhanced the bacterial adhesion performance, and the adhesion percentage increased with increasing Triton X-100 amount. The relative number of cells that adhered to $\mathrm{S}^{0}$ increased from $18.37 \%$ to $45.76 \%$ with the addition of $120 \mathrm{mg} \cdot \mathrm{L}^{-1}$ Triton X-100. This was because the increase in hydrophilicity of surface $S^{0}$ led to an increase of 
attachment ability of At. ferrooxidans with a good hydrophilic surface [31]. Therefore, we confirmed that the hydrophobic interaction plays a principal role in the adhesion of cells to the hydrophobic $S^{0}$ surface. Devasia et al. also reported that the greater hydrophobicity of bacterial cells could help in their adhesion to hydrophobic minerals like chalcopyrite and pyrite [32].

In sulfur medium, $\mathrm{S}^{0}$ is the sole energy source for At. ferrooxidans. When $S^{0}$ is biooxidized into sulfate, the solution $\mathrm{pH}$ value decreases, as illustrated by Reaction (1). Therefore, the sulfur oxidation rate could be evaluated indirectly by the change of the $\mathrm{pH}$ value of the medium. Figure 3B shows the influences of Triton X-100 on sulfur oxidation in the absence and presence of At. ferrooxidans. The results showed that the solution $\mathrm{pH}$ value dropped much faster in the presence of 30 to $90 \mathrm{mg} \cdot \mathrm{L}^{-1}$ Triton X-100. Among them, the effect of $60 \mathrm{mg} \cdot \mathrm{L}^{-1}$ Triton X-100 was the most obvious, leading to a maximum drop in $\mathrm{pH}$ value from 1.5 to 1.36 on day 20. These data indicated that the oxidative activity of At. ferrooxidans could be improved under the stress of Triton X-100 at appropriate concentrations. When the addition was higher than $120 \mathrm{mg} \cdot \mathrm{L}^{-1}$, sulfate production was depressed.

$$
2 \mathrm{~S}^{0}+3 \mathrm{O}_{2}+2 \mathrm{H}_{2} \mathrm{O} \stackrel{\text { At. ferrooxidans }}{\longrightarrow} 2 \mathrm{SO}_{4}^{2-}+4 \mathrm{H}^{+}
$$

Notably, in the absence of At. ferrooxidans, $\mathrm{S}^{0}$ was very slowly oxidized in acid solution, even when the Triton X-100 concentration increased to $200 \mathrm{mg} \cdot \mathrm{L}^{-1}$. This phenomenon demonstrates that $\mathrm{S}^{0}$ is inert and hardly oxidized at room temperature without a strong oxidizer, i.e., sulfur-oxidizing bacteria. This was in line with the observation by Knickerbocker et al. [33].

Based on the above results, it can be concluded that Triton X-100 did not accelerate the chemical oxidation of $S^{0}$, but induced the biological oxidation of $S^{0}$ owing to an increase in the bacterial adhesion to sulfur. The added Triton X-100 played a role of "bridge" in connecting $\mathrm{S}^{0}$ and cells. The positive correlation between the number of adhered bacteria and sulfur oxidation rate obtained by Porro et al. supported this hypothesis [34].

\subsection{The Leaching Efficiency of Chalcopyrite}

Figure 4 shows the influences of Triton X-100 at various concentrations on the copper extraction yield from chalcopyrite in the presence and absence of At. ferrooxidans. In the case of bacterial leaching, the leaching efficiency was sensitive to the concentration of Triton X-100. The surfactant at the dosage of 30 to $90 \mathrm{mg} \cdot \mathrm{L}^{-1}$ exerted remarkable catalytic effects. The optimum concentration was found to be $30 \mathrm{mg} \cdot \mathrm{L}^{-1}$, under which the copper extraction yield increased by $42.21 \%$ after 24 days of leaching. However, when the addition was above $120 \mathrm{mg} \cdot \mathrm{L}^{-1}$, there was a decrease in the copper extraction yield. This inhibition was associated with the negative effect of Triton X-100 on the iron oxidation activity of At. ferrooxidans (Figure 2).

In chemical leaching systems, the leaching efficiency was hardly influenced by Triton X-100 addition. Even at the $200 \mathrm{mg} \cdot \mathrm{L}^{-1}$ of dosage, the copper extraction yield increased from $75.50 \mathrm{mg} \cdot \mathrm{L}^{-1}$ to $81.22 \mathrm{mg} \cdot \mathrm{L}^{-1}$ in 24 days. Zhang et al. reported that polyethylene glycol could promote the chemical leaching of chalcopyrite, but not by much [23]. In contrast, the addition of another nonionic surfactant, Tween 20, had a negative effect toward chalcopyrite dissolution [17]. Hence, we believe that the key factor influencing the surfactant performance is its molecular structure rather than the ionic type. In addition, by comparing Figures 2 and 4, it can be seen that the decrease in the surface tension of solution has little benefit on the dissolution of chalcopyrite. 


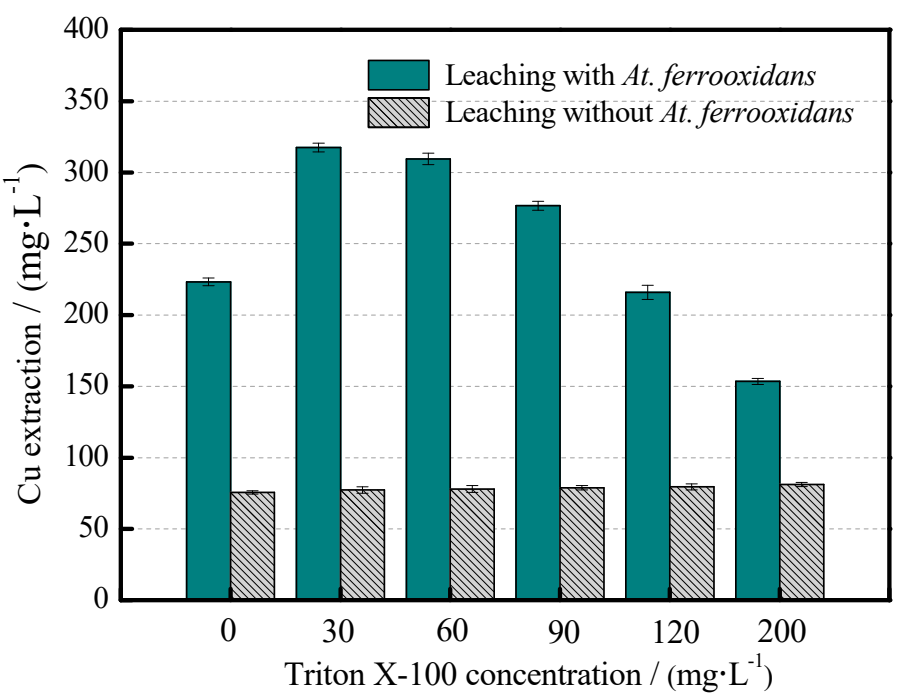

Figure 4. Influences of Triton X-100 on $\mathrm{Cu}$ extraction from chalcopyrite in the absence and presence of bacteria. Chalcopyrite $1 \%(w / v)$, bacteria inoculation $2 \times 10^{7}$ cells $\cdot \mathrm{mL}^{-1}$ for bioleaching systems, $\mathrm{NaF}$ $0.1 \mathrm{~g} \cdot \mathrm{L}^{-1}$ for abiotic leaching systems, initial $\mathrm{Fe}^{2+} 0 \mathrm{~g} \cdot \mathrm{L}^{-1}$, initial $\mathrm{pH} 2.0$, and leaching for 24 days.

\subsection{The Induction of Chalcopyrite Bioleaching}

A more detailed study of the optimal concentration $\left(30 \mathrm{mg} \cdot \mathrm{L}^{-1}\right)$ of Triton X-100 was conducted in systems without any energy substance like $\mathrm{Fe}^{2+}$ and $\mathrm{S}^{0}$. Changes in the solution $\mathrm{pH}$, the number of planktonic bacteria, and the concentrations of $\mathrm{Fe}^{2+}, \mathrm{Fe}^{3+}$, and $\mathrm{Cu}^{2+}$ ions are shown in Figure 5. Based on the variation regularity of these parameters, the whole process was divided into three stages: the first stage (day 0-3), the second stage (day 3-9), and the third stage (day 9-24).
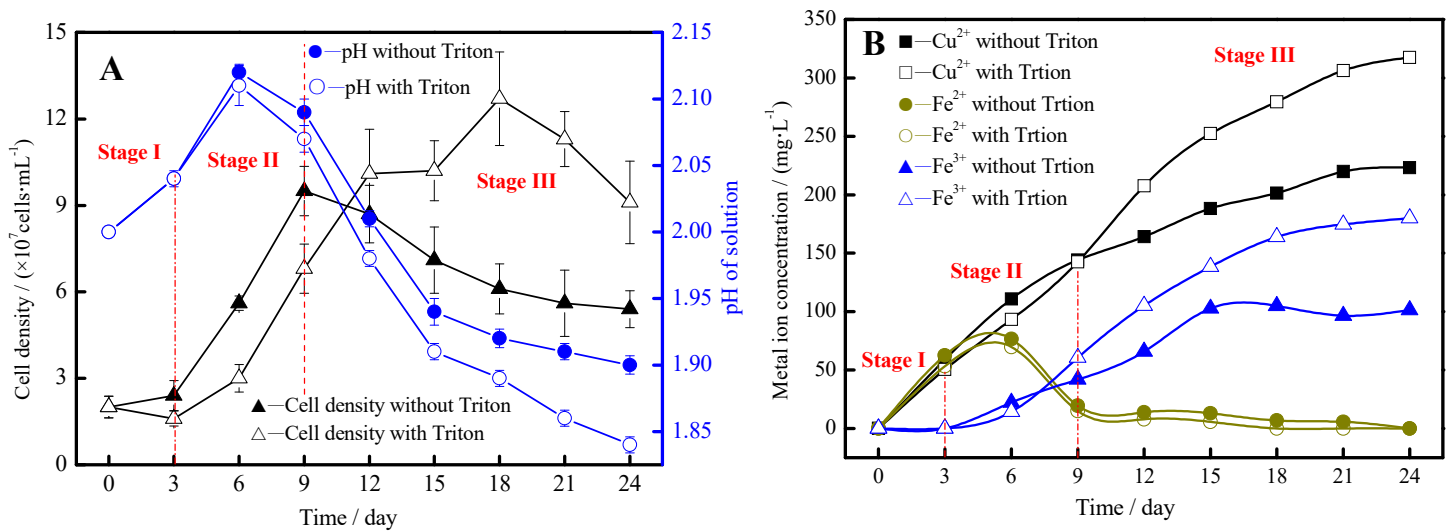

Figure 5. Influences of Triton $\mathrm{X}-100$ on the bioleaching behavior of chalcopyrite. (A) Variation of $\mathrm{pH}$ and cell density; (B) Variation of the concentrations of $\mathrm{Fe}^{2+}, \mathrm{Fe}^{3+}$ and $\mathrm{Cu}^{2+}$. (Chalcopyrite $1 \%(w / v)$, Triton X-100 $30 \mathrm{mg} \cdot \mathrm{L}^{-1}$, initial cell density $2 \times 10^{7}$ cells $\cdot \mathrm{mL}^{-1}$, initial $\mathrm{Fe}^{2+} 0 \mathrm{~g} \cdot \mathrm{L}^{-1}$, initial $\mathrm{pH} 2.0$, rotational speed $160 \mathrm{rpm}$, and temperature $30^{\circ} \mathrm{C}$ ).

In the first stage (day 0-3), the concentration of bacteria remained invariable due to the bacterial adaptive period both in the absence and presence of Triton X-100, as shown in Figure 5A. Moreover, it was observed that the solution $\mathrm{pH}$ and the concentration of $\mathrm{Fe}^{2+}$ increased. This was because the active sites like micro-pores, micro-cracks, and lattice defects on the chalcopyrite surface were first attacked by protons and dissolved oxygen (Reaction (2)), and at the same time $\mathrm{Fe}^{2+}$ and $\mathrm{S}^{0}$ were 
released. However, in terms of copper extraction, little change was observed between the control and the Triton $\mathrm{X}-100$ addition in this stage.

$$
\mathrm{CuFeS}_{2}+4 \mathrm{H}^{+}+\mathrm{O}_{2} \stackrel{\text { chemical }}{\longrightarrow} \mathrm{Cu}^{2+}+\mathrm{Fe}^{2+}+2 \mathrm{~S}^{0}+2 \mathrm{H}_{2} \mathrm{O}
$$

In the second stage (day 3-9), although $S^{0}$ also existed in the leaching system, water-soluble $\mathrm{Fe}^{2+}$ was more readily usable by At. ferrooxidans [35]. The accumulation of $\mathrm{Fe}^{2+}$ created a favorable condition for bacteria growth, and thus the number of bacteria increased rapidly, as shown in Figure 5A. However, the Triton X-100 addition delayed the bacteria growth, owing to its inhibition on the bacterial iron-oxidizing activity (Figure 2). As a result, the presence of Triton X-100 inhibited copper extraction from chalcopyrite to a certain degree.

In the third stage (day 9-24), the leaching solution $\mathrm{pH}$ declined gradually both with and without the Triton X-100 addition. This could be attributed to the fact that, although the oxidation of $\mathrm{Fe}^{2+}$ led to $\mathrm{H}^{+}$consumption (Reaction (3)), the oxidation of $\mathrm{S}^{0}$ into sulfate took place simultaneously (Reaction (1)). Remarkably, the solution $\mathrm{pH}$ declined from 1.90 (without Triton X-100) to 1.84 (with Triton X-100) after 24 days of leaching, suggesting an increase in the acid production due to $S^{0}$ oxidation. This evidence proved that Triton X-100 addition could induce the oxidative dissolution of $S^{0}$ formed in the leaching process. The increase of the bioavailability of $S^{0}$ provided more energy substrate to the bacteria growth in turn. Thus, without Triton $X-100$, the bacterial concentration reached a maximum of $9.5 \times$ $10^{7}$ cells $\cdot \mathrm{mL}^{-1}$ at day 9 , and then decreased afterward. By contrast, with Triton X-100, the bacterial concentration rose again after 9 days of leaching and reached a maximum of $1.3 \times 10^{8}$ cells $\cdot \mathrm{mL}^{-1}$ at day 18.

In the meantime, the rate of $\mathrm{Fe}^{2+}$ ions biooxidation (Reaction (3)) was enhanced because of higher a concentration of bacteria. Therefore, it was shown that the $\mathrm{Fe}^{3+}$ ions concentration increased from $101.41 \mathrm{mg} \cdot \mathrm{L}^{-1}$ (without Triton X-100) to $179.85 \mathrm{mg} \cdot \mathrm{L}^{-1}$ (with Triton X-100) on day 24 . However, in the absence of Triton $\mathrm{X}-100$, the concentration of $\mathrm{Fe}^{3+}$ ions no longer increased after 15 days, owing to the precipitation of jarosite, as expressed by Reaction (4). According to Vera et al. [36], the increase in concentration of $\mathrm{Fe}^{3+}$ ions, as an oxidant, could help the chemical oxidation of chalcopyrite, as expressed by Reaction (5). As a result, the addition of Triton X-100 could effectively enhance the dissolution of chalcopyrite between day 9 and day 24, and the final copper leaching recovery was 223.24 and $317.46 \mathrm{mg} \cdot \mathrm{L}^{-1}$ without and with Triton $\mathrm{X}-100$ addition, respectively.

$$
\begin{gathered}
4 \mathrm{Fe}^{2+}+\mathrm{O}_{2}+4 \mathrm{H}^{+} \stackrel{\text { At. ferrooxidans }}{\longrightarrow} 4 \mathrm{Fe}^{3+}+2 \mathrm{H}_{2} \mathrm{O} \\
3 \mathrm{Fe}^{3+}+2 \mathrm{SO}_{4}^{2-}+6 \mathrm{H}_{2} \mathrm{O}+\mathrm{M}^{+} \rightarrow \mathrm{MFe}_{3}\left(\mathrm{SO}_{4}\right)_{2}(\mathrm{OH})_{6}+6 \mathrm{M}^{+} \\
\mathrm{CuFeS}_{2}+4 \mathrm{Fe}^{3+} \rightarrow \mathrm{Cu}^{2+}+5 \mathrm{Fe}^{2+}+2 \mathrm{~S}^{0}
\end{gathered}
$$

where $M$ represents $\mathrm{K}^{+}, \mathrm{NH}_{4}{ }^{+}, \mathrm{Na}^{+}$, or $\mathrm{H}_{3} \mathrm{O}^{+}$.

\subsection{Analysis of Chalcopyrite Surface after Leaching}

Figure 6 presents the XRD results of chalcopyrite after being bioleached with and without Triton $\mathrm{X}-100$. The original chalcopyrite sample was used as a control. Results showed that potassium jarosite $\left(\mathrm{KFe}_{3}\left(\mathrm{SO}_{4}\right)_{2}(\mathrm{OH})_{6}\right)$ and elemental sulfur $\left(\mathrm{S}^{0}\right)$ were generated in the process of chalcopyrite biooxidation, in accordance with the finding of Bevilaqua et al. [37]. This also indicated that $S^{0}$ formed in the process could not be efficiently oxidized and dissolved even in the presence of At. ferrooxidans. By contrast, in the presence of Triton $X-100, S^{0}$ was not found in the leaching residue, suggesting that the proposed surfactant could induce the biooxidation of $S^{0}$. These observations agreed well with the results shown in Figure 3. 


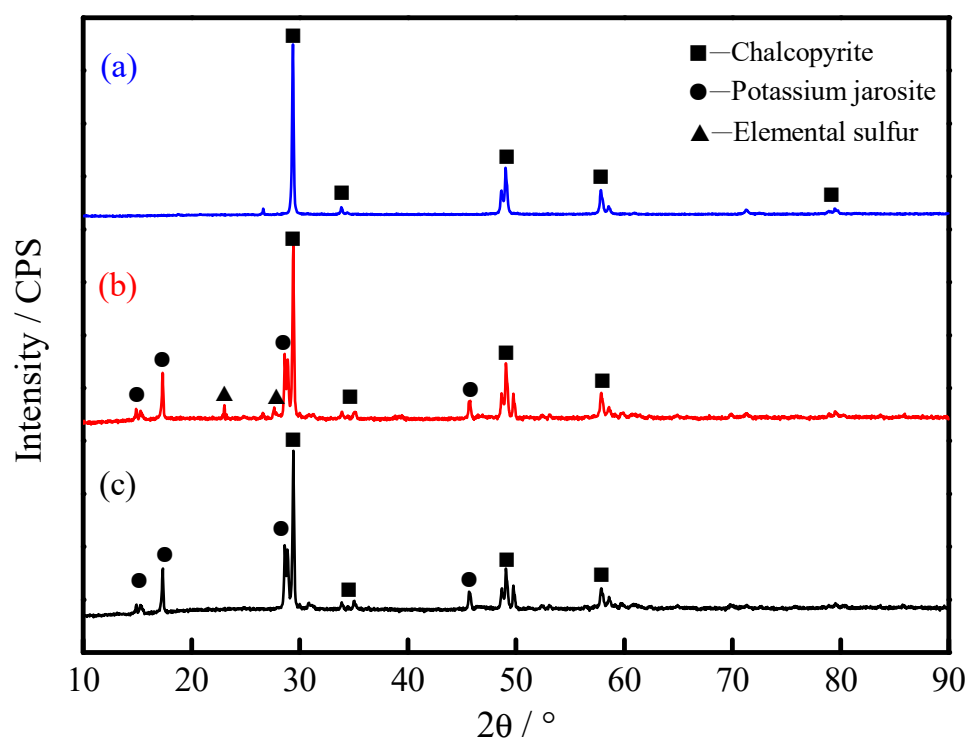

Figure 6. XRD analysis of (a) the original chalcopyrite, and the chalcopyrite bioleached (b) without Triton X-100 and (c) with Triton X-100. (Chalcopyrite 1\% $(w / v)$, Triton X-100 $30 \mathrm{mg} \cdot \mathrm{L}^{-1}$, initial cell density $2 \times 10^{7}$ cells $\cdot \mathrm{mL}^{-1}$, initial $\mathrm{Fe}^{2+} 0 \mathrm{~g} \cdot \mathrm{L}^{-1}$, initial $\mathrm{pH} 2.0$, rotational speed $160 \mathrm{rpm}$, temperature $30{ }^{\circ} \mathrm{C}$, and leaching for 24 days).

Figure 7 presents the surface micro-morphologies of the chalcopyrite bioleached without and with Triton X-100. Without the surfactant, the surface of mineral particles was covered with a large accumulation of flocculent precipitates. These insoluble precipitates (i.e., potassium jarosite and elemental sulfur) were detrimental to the leaching reaction, resulting in a decrease of the leaching rate (Figure 5B). Meanwhile, only a few signs of corrosion were observed on the surface of chalcopyrite. However, in the presence of Triton X-100, the surface was eroded strongly. Scale- and ladder-like structure was displayed, and only a small amount of precipitate was observed on the mineral surface. These results indicated that the appearance of leached chalcopyrite surface was notably changed by the addition of Triton X-100.
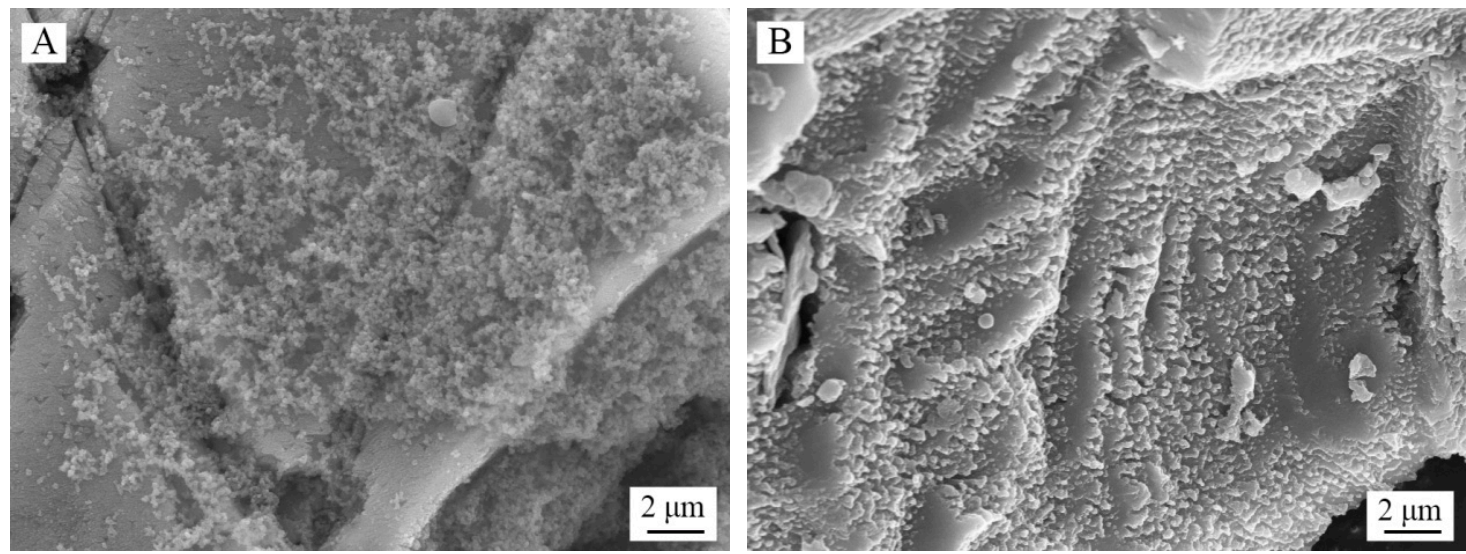

Figure 7. SEM results of chalcopyrite bioleached (A) without Triton X-100 and (B) with Triton X-100. (Chalcopyrite $1 \%(w / v)$, Triton X-100 $30 \mathrm{mg} \cdot \mathrm{L}^{-1}$, initial cell density $2 \times 10^{7}$ cells $\cdot \mathrm{mL}^{-1}$, initial Fe $\mathrm{Fe}^{2+}$ $0 \mathrm{~g} \cdot \mathrm{L}^{-1}$, initial $\mathrm{pH} 2.0$, rotational speed $160 \mathrm{rpm}$, temperature $30^{\circ} \mathrm{C}$, and leaching for 24 days).

It is worth noting that few cells can be observed in Figure 7. The similar phenomenon can also be observed in other studies [38-40]. However, if the samples after bioleaching were pretreated using a series of operations including fixing, dehydrating, critical point drying, or freeze-drying, the cells attached to mineral surfaces would be clearly visible [41-43]. Thus, the loss of cells was probably due 
to the damage of cell structure, but this hardly affected the observation of the passivation layer formed on the mineral surface.

Figure 8 represents the XPS spectra of the surface of chalcopyrite bioleached with and without Triton X-100. In terms of $\mathrm{Cu} 2 p$, two spectra peaks of 932.1 and $951.95 \mathrm{eV}$ existed whether Triton X-100 was added or not. This observation indicated that copper on the mineral surface might be in a +2 valence state, according to Todd et al. [44]. Thus, it was considered that the Triton X-100 addition could not change migration path of copper during the oxidation of chalcopyrite.
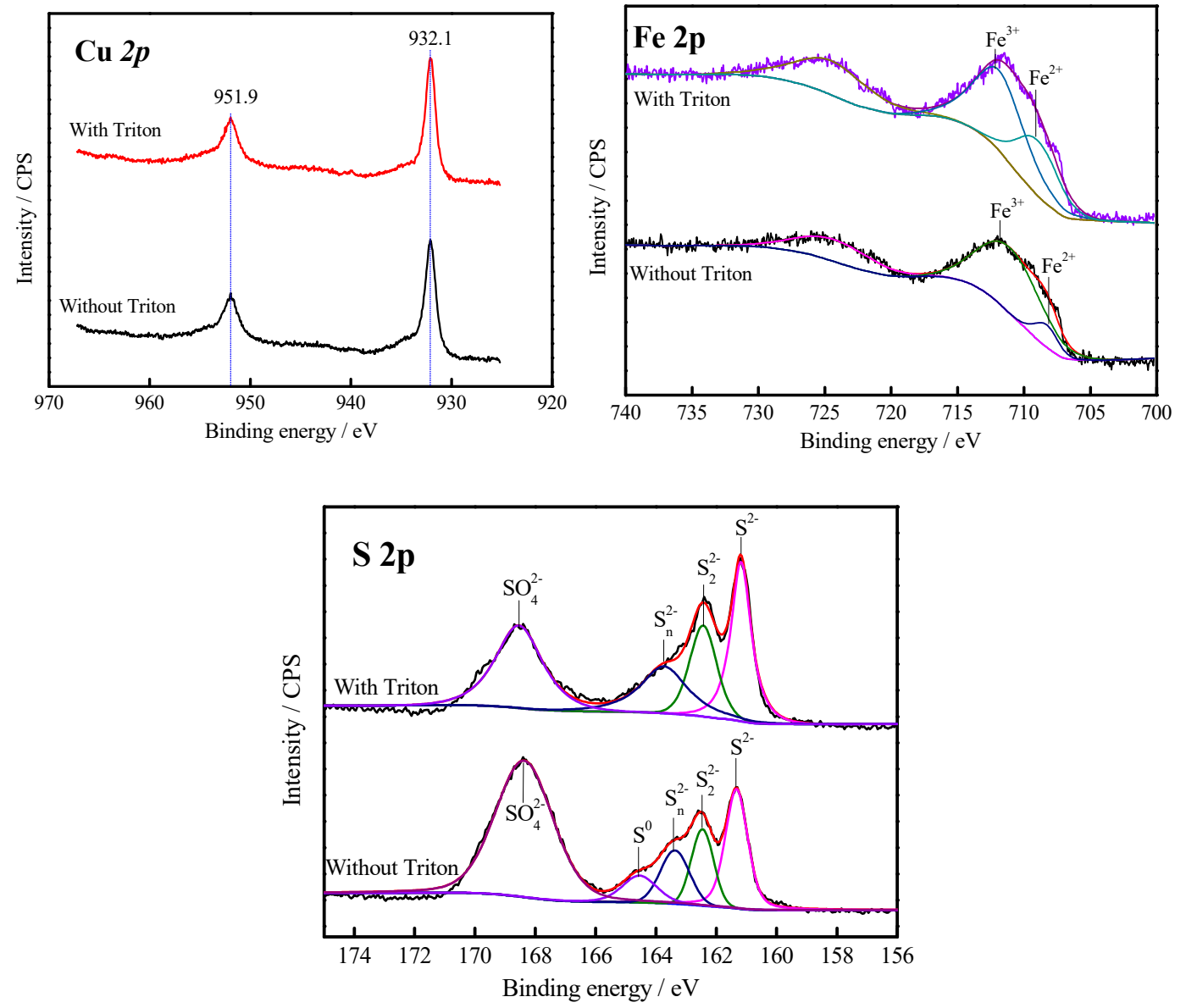

Figure 8. Cu $2 p$, Fe $2 p$ and S $2 p$ XPS spectra of chalcopyrite bioleached without and with Triton X-100. (Chalcopyrite $1 \%(w / v)$, Triton X-100 $30 \mathrm{mg} \cdot \mathrm{L}^{-1}$, initial cell density $2 \times 10^{7}$ cells $\cdot \mathrm{mL}^{-1}$, initial Fe ${ }^{2+}$ $0 \mathrm{~g} \cdot \mathrm{L}^{-1}$, initial $\mathrm{pH} 2.0$, rotational speed $160 \mathrm{rpm}$, temperature $30^{\circ} \mathrm{C}$, and leaching for 24 days).

There are numerous studies on the oxidation state for $\mathrm{Cu}, \mathrm{Fe}$, and $\mathrm{S}$ in the bulk structure of chalcopyrite, but two different opinions exist on its structure: one is $\mathrm{Cu}^{+} \mathrm{Fe}^{3+} \mathrm{S}_{2}$ [45], the other is $\mathrm{Cu}^{2+} \mathrm{Fe}^{2+} \mathrm{S}_{2}[44,46]$. Remarkably, the small separation of the energies between the main peak of $\mathrm{Cu}$ (II)-oxides and sulfides compared to the peak of $\mathrm{Cu}(\mathrm{I})$-oxides and sulfides requires extreme care [45]. Coincidentally, the main $\mathrm{Cu} 2 \mathrm{p}$ peaks of these two samples were centered at $932.1 \mathrm{eV}$, which were in good agreement with the value of the $\mathrm{Cu} 2 \mathrm{p}$ peak of $\mathrm{CuS}$, according to the studies of Zhao and Ghahremaninezhad et al. [47,48]. This indicated that CuS might be generated, as an intermediate product at a late stage of chalcopyrite leaching. Córdoba and He et al. [38,49] also demonstrated the presence of CuS during the oxidation of chalcopyrite, though short-lived. Thus, Reaction (5) should be amended and divided into two steps. First, it was oxidized, forming CuS as an intermediary product:

$$
\mathrm{CuFeS}_{2}+2 \mathrm{Fe}^{3+} \rightarrow \mathrm{CuS}+3 \mathrm{Fe}^{2+}+\mathrm{S}^{0}
$$


Then, CuS was oxidized by ferric ion, releasing copper ions:

$$
\mathrm{CuS}+2 \mathrm{Fe}^{3+} \rightarrow \mathrm{Cu}^{2+}+2 \mathrm{Fe}^{2+}+\mathrm{S}^{0}
$$

From the results of Fe $2 p$ spectra, the strongest peak appeared near $711.5 \mathrm{eV}$, as the emission characteristics of $\mathrm{Fe}^{3+}$, indicating that iron(III) (hydro)oxide productions at the surface had been formed at the mineral's surface [50]. In this study, this mainly referred to potassium jarosite, as shown in Figure 6. The peak at $708.6 \pm 0.2 \mathrm{eV}$ was assigned to Fe(II)-S, which came from the chalcopyrite crystal structure [51]. Also, the peak at $724.4 \mathrm{eV}$ could be attributed to the other spin orbit component of iron bulk chalcopyrite, according to the result of Harmer et al. [51]. The increase in intensity of the $\mathrm{Fe}^{2+}$ peak indicated that more fresh surface was exposed from the passivation layer under the effect of Triton X-100.

From the results of $S 2 p$ spectra, it was shown that $S^{0}(164.5 \mathrm{eV})$ was detected when chalcopyrite was bioleached without additives [52]. This phenomenon demonstrated that $S^{0}$, as an intermediate in the leaching process, was not efficiently oxidized by the sulfur-oxidizing bacteria (i.e., At. ferrooxidans) and easily stored on the mineral surface. However, in the presence of Triton X-100, $\mathrm{S}^{0}$ was not detected, confirming that Triton $X-100$ addition could eliminate $S^{0}$ from the mineral surface, which was accordant with XRD results of the leach residues in Figure 6.

Furthermore, Triton X-100 decreased the intensity of the $\mathrm{SO}_{4}^{2-}$ peak $(168.4 \mathrm{eV})$, which suggested that the amount of jarosite formed on the mineral surface had been removed [53]. This can be attributed to two reasons: (i) the solubilization of formed $\mathrm{S}^{0}$ dispersed the oxidation products from the mineral surface, which was similar with the role of Tweens in cobalt ore bioleaching [29]; and (ii) the decrease in solution $\mathrm{pH}$ value (below 1.9) delayed the jarosite formation to a certain extent [54].

In addition, monosulfid $\mathrm{S}^{2-}(161.3 \mathrm{eV})$, disulfide $\mathrm{S}_{2}^{2-}(162.5 \mathrm{eV})$, and polysulfide $\mathrm{S}_{\mathrm{n}}^{2-}(163.4 \mathrm{eV})$ were also present on the surface whether Triton X-100 was added or not [50]. The peak at $161.3 \mathrm{eV}$ was generated from the chalcopyrite crystal structure [53]. Previous studies showed that the oxidation reaction of sulfide minerals followed two pathways: (i) the thiosulfate pathway, $\mathrm{S}^{2-} \rightarrow \mathrm{S}^{2+} \rightarrow \mathrm{S}^{6+}$; and (ii) the polysulfide pathway, $\mathrm{S}^{2-} \rightarrow \mathrm{S}^{0} \rightarrow \mathrm{S}^{6+}[36,55]$. In the present study, we speculated that the oxidation of chalcopyrite occurred in the second way, and the valence-state changes of sulfur followed the order as below: $\mathrm{S}^{2-} \rightarrow \mathrm{S}_{2}^{2-} \rightarrow \mathrm{S}_{\mathrm{n}}^{2-} \rightarrow \mathrm{S}^{0} \rightarrow \mathrm{SO}_{4}^{2-}$. However, it was important to note that neither disulfide $S_{2}^{2-}$ nor polysulfide $S_{n}^{2-}$ species were directly detected by XRD results, indicating that these intermediates were amorphous and unstable which would be ultimately oxidized into sulfate.

\subsection{Model of the Enhancement of Bioleaching}

Based on the above investigations, a model for enhancing chalcopyrite bioleaching using surfactant Triton X-100 was proposed, as shown in Figure 9. The chalcopyrite bioleaching process could be regarded as a three-step process:

(i) In the first stage, the addition of Triton X-100 could hardly influence chalcopyrite leaching. Chalcopyrite was initially attacked by protons, simultaneously releasing ferrous iron and elemental sulfur, as Reaction (2) proceeded.

(ii) In the second stage, the bacterial leaching of chalcopyrite is slightly prevented by the addition of Triton X-100. This was mainly because the surfactant addition had a negative effect on iron-oxidizing activity of the leaching bacteria, and the bacteria would first use soluble $\mathrm{Fe}^{2+}$ rather than insoluble $S^{0}$ as the energy resource, as illustrated by Reactions (1) and (3).

(iii) In the third stage, chalcopyrite bioleaching was promoted under the induction of Triton X-100, and the copper extraction efficiency increased remarkably. Triton X-100 induced the bioavailability of formed $\mathrm{S}^{0}$, consequently destroying the structure of the passivation layer. On the other hand, the decrease of the leaching solution $\mathrm{pH}$ delayed jarosite formation (Reaction (4)), and favored the "indirect" oxidation of chalcopyrite (Reaction (5)), which in turn maintained the ongoing dissolution of chalcopyrite. 


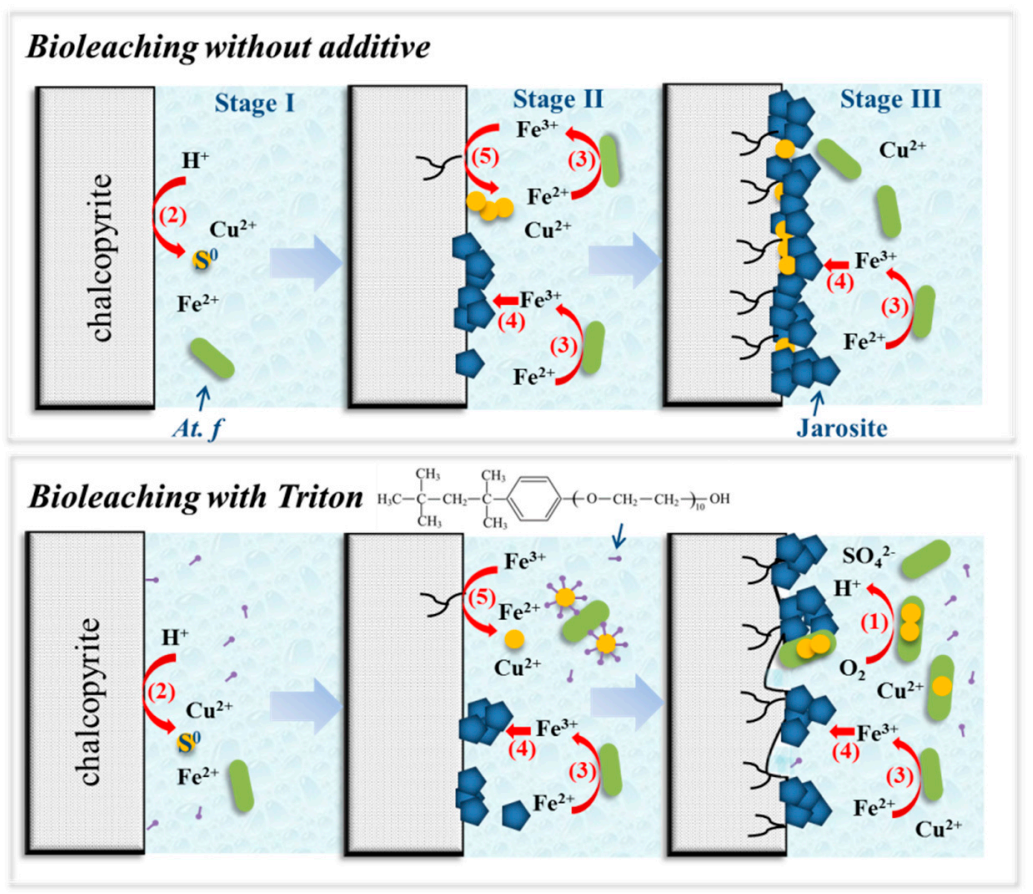

Figure 9. Proposed schematic diagram of enhancing chalcopyrite bioleaching under the induction of Triton X-100. The numbers (1)-(5) represent the Reactions (1)-(5).

\section{Conclusions}

The presented work gives insights into the mechanism of enhancing meso-acidophilic chalcopyrite bioleaching using the surfactant Triton X-100. Results showed that the optimum dosage of Triton $\mathrm{X}-100$ was $30 \mathrm{mg} \cdot \mathrm{L}^{-1}$, and the copper extraction yield increased by $42.21 \%$ compared to the normal bioleaching without an additive. However, the surfactant itself had no ability to leach chalcopyrite. The presence of Triton X-100 induced the biooxidation of $S^{0}$, owing to more rapid contact between the bacteria and sulfur particle, but it decreased the iron-oxidizing activity of At. ferrooxidans. During the bioleaching process, the addition of Triton X-100 increased the concentrations of bacteria and removed inhibitory jarosite and $S^{0}$ from the mineral surface, thereby accelerating the chalcopyrite oxidation. This study indicates that increasing the sulfur-oxidizing activity of bacteria can enhance chalcopyrite bioleaching, and the application of the surfactant Triton X-100 is a potential method.

Author Contributions: R.Z. and C.S. designed the experiment, performed the study, and wrote the manuscript. J.K. and H.Z. performed the experiment and the analyses of leached chalcopyrite surface. D.W. and Y.X. coordinated the study and modified the draft of the manuscript. All authors gave final approval for publication.

Funding: This research was funded by the National Natural Science Foundation of China (No. 51804020), the China Postdoctoral Science Foundation (No. 2018M631343), and the Fundamental Research Funds for the Central Universities (No. FRF-TP-17-025A1).

Acknowledgments: We thank Emre Naci Altun (Middle East Technical University, Turkey) for providing advice on manuscript preparation.

Conflicts of Interest: The authors declare no conflict of interest.

\section{References}

1. Panda, S.; Biswal, A.; Mishra, S.; Panda, P.K.; Pradhan, N.; Mohapatra, U. Reductive dissolution by waste newspaper for enhanced meso-acidophilic bioleaching of copper from low grade chalcopyrite: A new concept of biohydrometallurgy. Hydrometallurgy 2015, 153, 98-105. [CrossRef]

2. Bevilaqua, D.; Leite, A.L.L.C.; Garcia, O.; Tuovinen, O.H. Oxidation of chalcopyrite by Acidithiobacillus ferrooxidans and Acidithiobacillus thiooxidans in shake flasks. Process. Biochem. 2002, 38, 587-592. [CrossRef] 
3. Pathak, A.; Morrison, L.; Healy, M.G. Catalytic potential of selected metal ions for bioleaching, and potential techno-economic and environmental issues: A critical review. Bioresour. Technol. 2017, 229, 211-221. [CrossRef] [PubMed]

4. Watling, H.R. Chalcopyrite hydrometallurgy at atmospheric pressure: 1. review of acidic sulfate, sulfate-chloride and sulfate-nitrate process options. Hydrometallurgy 2013, 140, 163-180. [CrossRef]

5. Fu, K.; Lin, H.; Mo, X.; Wang, H.; Wen, H.; Wen, Z. Comparative study on the passivation layers of copper sulphide minerals during bioleaching. Int. J. Miner. Met. Mater. 2012, 19, 886-892. [CrossRef]

6. Wang, J.; Gan, X.; Zhao, H.; Hu, M.; Li, K.; Qin, W.; Qiu, G. Dissolution and passivation mechanisms of chalcopyrite during bioleaching: DFT calculation, XPS and electrochemistry analysis. Miner. Eng. 2016, 98, 264-278. [CrossRef]

7. Hedrich, S.; Joulian, C.; Graupner, T.; Schippers, A.; Guézennec, A.G. Enhanced chalcopyrite dissolution in stirred tank reactors by temperature increase during bioleaching. Hydrometallurgy 2018, 179, 125-131. [CrossRef]

8. Liu, H.; Xia, J.; Nie, Z.; Ma, C.; Zheng, L.; Hong, C.; Wen, W. Bioleaching of chalcopyrite by Acidianus manzaensis under different constant pH. Miner. Eng. 2016, 98, 80-89. [CrossRef]

9. Lotfalian, M.; Ranjbar, M.; Fazaelipoor, M.H.; Schaffie, M.; Manafi, Z. The effect of redox control on the continuous bioleaching of chalcopyrite concentrate. Miner. Eng. 2015, 81, 52-57. [CrossRef]

10. Abdollahi, H.; Noaparast, M.; Shafaei, S.Z.; Manafi, Z.; Muñoz, J.A.; Tuovinen, O.H. Silver-catalyzed bioleaching of copper, molybdenum and rhenium from a chalcopyrite-molybdenite concentrate. Int. Biodeterior. Biodegrad. 2015, 104, 194-200. [CrossRef]

11. Zhang, W.; Gu, S. Catalytic effect of activated carbon on bioleaching of low-grade primary copper sulfide ores. Trans. Nonferr. Met. Soc. China 2007, 17, 1123-1127. [CrossRef]

12. Ilankoon, I.M.S.K.; Tang, Y.; Ghorbani, Y.; Northey, S.; Yellishetty, M.; Deng, X.; McBride, D. The current state and future directions of percolation leaching in the Chinese mining industry: Challenges and opportunities. Miner. Eng. 2018, 125, 206-222. [CrossRef]

13. Liu, W.; Yang, H.; Song, Y.; Tong, L. Catalytic effects of activated carbon and surfactants on bioleaching of cobalt ore. Hydrometallurgy 2015, 152, 69-75. [CrossRef]

14. Deng, T.; Liao, M.; Wang, M.; Chen, Y.; Belzile, N. Investigations of accelerating parameters for the biooxidation of low-grade refractory gold ores. Miner. Eng. 2000, 13, 1543-1553. [CrossRef]

15. Lan, Z.; Hu, Y.; Qin, W. Effect of surfactant OPD on the bioleaching of marmatite. Miner. Eng. 2009, 22, 10-13. [CrossRef]

16. Dehghan, R.; Dianati, M. The effects of $\mathrm{Pb}-\mathrm{Zn}$ flotation reagents on the bioleaching process by mesophilic bacteria. Int. J. Miner. Process. 2015, 143, 80-86. [CrossRef]

17. Hiroyoshi, N.; Nakamura, T.; Tsunekawa, M.; Hirajima, T.; Ito, M. Enhancement in bacterial leaching of chalcopyrite by polyoxyethylene sorbitan monolaurate addition. Shigen-to-Sozai 1995, 111, 943-948. [CrossRef]

18. Peng, A.; Liu, H.; Nie, Z.; Xia, J. Effect of surfactant Tween-80 on sulfur oxidation and expression of sulfur metabolism relevant genes of Acidithiobacillus ferrooxidans. Trans. Nonferr. Met. Soc. China 2012, 22, 3147-3155. [CrossRef]

19. Torma, A.E.; Gabra, G.G.; Guay, R.; Silver, M. Effects of surface active agents on the oxidation of chalcopyrite by thiobacillus ferrooxidans. Hydrometallurgy 1976, 4, 301-309. [CrossRef]

20. Zhu, Y.; Xu, G.; Xin, X.; Zhang, H.; Shi, X. Surface tension and dilational viscoelasticity of water in the presence of surfactants tyloxapol and Triton X-100 with cetyl trimethylammonium bromide at $25{ }^{\circ} \mathrm{C}$. J. Chem. Eng. Data 2009, 54, 989-995. [CrossRef]

21. Sałek, K.; Kaczorek, E.; Guzik, U. Bacterial properties changing under Triton X-100 presence in the diesel oil biodegradation systems: From surface and cellular changes to mono- and dioxygenases activities. Environ. Sci. Pollut. Res. 2015, 22, 4305-4315. [CrossRef] [PubMed]

22. Zhang, R.; Wei, D.; Liu, W.; Gao, S. Effects of Triton X-100 on oxidative activity of Acidithiobacillus ferrooxidans and on chalcopyrite bioleaching. J. Northeast. Univ. Natl. Sci. 2016, 6, 861-865. (In Chinese)

23. Zhang, R.; Wei, D.; Shen, Y.; Liu, W.; Lu, T.; Han, C. Catalytic effect of polyethylene glycol on sulfur oxidation in chalcopyrite bioleaching by Acidithiobacillus ferrooxidans. Miner. Eng. 2016, 95, 74-78. [CrossRef]

24. Peng, T.; Zhou, D.; Liu, X.; Yu, R.; Jiang, T.; Gu, G.; Zeng, W. Enrichment of ferric iron on mineral surface during bioleaching of chalcopyrite. Trans. Nonferr. Met. Soc. China 2016, 26, 544-550. [CrossRef] 
25. Zhao, H.; Wang, B.; Li, Y.; Song, Q.; Zhao, Y.; Zhang, R.; Shu, X. Effect of chemical fractionation treatment on structure and characteristics of pyrolysis products of Xinjiang long flame coal. Fuel 2018, 234, 1193-1204. [CrossRef]

26. Hao, X.; Liu, X.; Zhu, P.; Chen, A.; Liu, H.; Yin, H.; Liang, Y. Carbon material with high specific surface area improves complex copper ores' bioleaching efficiency by mixed moderate thermophiles. Minerals 2018, 8 , 301. [CrossRef]

27. Tuttle, J.H.; Dugan, P.R. Inhibition of growth, iron, and sulfur oxidation in Thiobacillus ferrooxidans by simple organic compounds. Can. J. Microbiol. 1976, 22, 719-730. [CrossRef]

28. Jafari, M.; Shafaei, S.Z.A.; Abdollahi, H.; Gharabaghi, M.; Chehreh, C.S. A comparative study on the effect of flotation reagents on growth and iron oxidation activities of Leptospirillum ferrooxidans and Acidithiobacillus ferrooxidans. Minerals 2016, 7, 2. [CrossRef]

29. Liu, W.; Zhang, S.; Sun, F.; Liu, C. Catalytic effect of a combined silver and surfactant catalyst on cobalt ore bioleaching. JOM 2018, 9, 1-6. [CrossRef]

30. Pakostova, E.; Mandl, M.; Tuovinen, O.H. Cellular ATP and biomass of attached and planktonic sulfur-oxidizing Acidithiobacillus ferrooxidans. Process Biochem. 2013, 48, 1785-1788. [CrossRef]

31. Tan, S.; Chen, M. Early stage adsorption behaviour of Acidithiobacillus ferrooxidans on minerals I: An experimental approach. Hydrometallurgy 2013, 119-120, 87-94. [CrossRef]

32. Devasia, P.; Natarajan, K.A. Adhesion of Acidithiobacillus ferrooxidans to mineral surfaces. Int. J. Miner. Process. 2010, 94, 135-139. [CrossRef]

33. Knickerbocker, C.; Nordstrom, D.K.; Southam, G. The role of "blebbing" in overcoming the hydrophobic barrier during biooxidation of elemental sulfur by Thiobacillus thiooxidans. Chem. Geol. 2000, 169, 425-433. [CrossRef]

34. Porro, S.; Ramírez, S.; Reche, C.; Curutchet, G.; Alonso-Romanowski, S.; Donati, E. Bacterial attachment: Its role in bioleaching processes. Process Biochem. 1997, 32, 573-578. [CrossRef]

35. Valdés, J.; Pedroso, I.; Quatrini, R.; Dodson, R.; Tettelin, H.; Blake, R. Acidithiobacillus ferrooxidans metabolism: From genome sequence to industrial applications. BMC Genom. 2008, 9, 597. [CrossRef] [PubMed]

36. Vera, M.; Schippers, A.; Sand, W. Progress in bioleaching: Fundamentals and mechanisms of bacterial metal sulfide oxidation-Part A. Appl. Microbiol. Biotechnol. 2013, 97, 7529-7541. [CrossRef] [PubMed]

37. Bevilaqua, D.; Lahti, H.; Suegama, P.H.; Benedetti, A.V.; Puhakka, J.A. Effect of Na-chloride on the bioleaching of a chalcopyrite concentrate in shake flasks and stirred tank bioreactors. Hydrometallurgy 2013, 138, 1-13. [CrossRef]

38. He, H.; Xia, J.; Yang, Y.; Jiang, H.; Xiao, C.; Zheng, L.; Qiu, G. Sulfur speciation on the surface of chalcopyrite leached by Acidianus manzaensis. Hydrometallurgy 2009, 99, 45-50. [CrossRef]

39. Liu, H.; Xia, J.; Nie, Z. Relatedness of $\mathrm{Cu}$ and $\mathrm{Fe}$ speciation to chalcopyrite bioleaching by Acidithiobacillus ferrooxidans. Hydrometallurgy 2015, 156, 40-46. [CrossRef]

40. Li, L.; Lv, Z.; Yuan, X. Effect of L-glycine on bioleaching of collophanite by Acidithiobacillus ferrooxidans. Int. Biodeterior. Biodegrad. 2013, 85, 156-165. [CrossRef]

41. Castro, C.; Donati, E. Effects of different energy sources on cell adhesion and bioleaching of a chalcopyrite concentrate by extremophilic archaeon Acidianus copahuensis. Hydrometallurgy 2016, 162, 49-56. [CrossRef]

42. Zhao, X.; Wang, R.; Lu, X.; Lu, J.; Li, C.; Li, J. Bioleaching of chalcopyrite by Acidithiobacillus ferrooxidans. Miner. Eng. 2013, 53, 184-192. [CrossRef]

43. Lara, R.; García-Meza, J.; González, I.; Cruz, R. Influence of the surface speciation on biofilm attachment to chalcopyrite by Acidithiobacillus thiooxidans. Appl. Microbial. Biot. 2013, 97, 2711-2724. [CrossRef] [PubMed]

44. Todd, E.C.; Sherman, D.M.; Purton, J.A. Surface oxidation of chalcopyrite $\left(\mathrm{CuFeS}_{2}\right)$ under ambient atmospheric and aqueous $(\mathrm{pH} 2-10)$ conditions: $\mathrm{Cu}, \mathrm{Fe}$ L- and $\mathrm{O}$ K-edge X-ray spectroscopy. Geochim. Cosmochim. Acta 2013, 67, 2137-2146. [CrossRef]

45. Pearce, C.I.; Pattrick, R.A.D.; Vaughan, D.J.; Henderson, C.M.B.; Van der Laan, G. Copper oxidation state in chalcopyrite: Mixed Cu d9 and d10 characteristics. Geochim. Cosmochim. Acta 2006, 70, 4635-4642. [CrossRef]

46. Mikhlin, Y.; Tomashevich, Y.; Tauson, V.; Vyalikh, D.; Molodtsov, S.; Szargan, R. A comparative X-ray absorption near-edge structure study of bornite, $\mathrm{Cu}_{5} \mathrm{FeS}_{4}$, and chalcopyrite, $\mathrm{CuFeS}_{2}$. J. Electron. Spectrosc. 2005, 142, 83-88. [CrossRef] 
47. Zhao, H.; Wang, J.; Tao, L.; Cao, P.; Yang, C.; Qin, W.; Qiu, G. Roles of oxidants and reductants in bioleaching system of chalcopyrite at normal atmospheric pressure and $45^{\circ} \mathrm{C}$. Int. J. Miner. Process. 2017, 162, 81-91. [CrossRef]

48. Ghahremaninezhad, A.; Dixon, D.G.; Asselin, E. Electrochemical and XPS analysis of chalcopyrite $\left(\mathrm{CuFeS}_{2}\right)$ dissolution in sulfuric acid solution. Electrochim. Acta 2013, 87, 97-112. [CrossRef]

49. Córdoba, E.M.; Muñoz, J.A.; Blázquez, M.L.; González, F.; Ballester, A. Leaching of chalcopyrite with ferric ion. Part II: Effect of redox potential. Hydrometallurgy 2008, 93, 88-96. [CrossRef]

50. Acres, R.G.; Harmer, S.L.; Beattie, D.A. Synchrotron XPS studies of solution exposed chalcopyrite, bornite, and heterogeneous chalcopyrite with bornite. Int. J. Miner. Process. 2010, 94, 43-51. [CrossRef]

51. Harmer, S.L.; Thomas, J.E.; Fornasiero, D.; Gerson, A.R. The evolution of surface layers formed during chalcopyrite leaching. Geochim. Cosmochim. Acta 2006, 70, 4392-4402. [CrossRef]

52. Zhao, H.; Huang, X.; Wang, J.; Li, Y.; Liao, R.; Wang, X. Comparison of bioleaching and dissolution process of p-type and n-type chalcopyrite. Miner. Eng. 2017, 109, 153-161. [CrossRef]

53. Acres, R.G.; Harmer, S.L.; Shui, H.; Chen, C.; Beattie, D.A. Synchrotron scanning photoemission microscopy of homogeneous and heterogeneous metal sulfide minerals. J. Synchrotron Radiat. 2011, 18, 649-657. [CrossRef] [PubMed]

54. Pradhan, N.; Nathsarma, K.C.; Rao, K.S.; Sukla, L.B.; Mishra, B.K. Heap bioleaching of chalcopyrite: A review. Miner. Eng. 2008, 21, 355-365. [CrossRef]

55. Li, Y.; Kawashima, N.; Li, J.; Chandra, A.P.; Gerson, A.R. A review of the structure, and fundamental mechanisms and kinetics of the leaching of chalcopyrite. Adv. Colloid Interface Sci. 2013, 197-198, 1-32. [CrossRef] [PubMed]

(C) 2018 by the authors. Licensee MDPI, Basel, Switzerland. This article is an open access article distributed under the terms and conditions of the Creative Commons Attribution (CC BY) license (http:/ / creativecommons.org/licenses/by/4.0/). 